\title{
FM IN MOBILE AND RADIO IN CAR PANEL - PATHWAYS TO THE FUTURE OF RADIO
}

Chair: Marco Túlio Nascimento - director of ZYDigital / SET

As the smartphone is virtually the universal device for media consumption, it is absolutely strategic that the radio is present in it. Ironically, most cell phones have the FM reception chip, however, only a minority have this reception activated. Noting this, NAB has begun a campaign to activate these chips. At the same time, the NextRadio hybrid radio model was launched on the American market, bringing together FM audio reception with 3G / 4G internet metadata reception. Following the same movement, the Brazilian broadcasters began to mobilize to promote the activation of the FM chips in the smartphones here. This will be the focus of this panel, the activation of FM in mobile phones. The American case, the promotion initiatives in Brazil and the proposed regulation will be presented. The panel will also include a presentation on the RDC project, a technology that allows the display of the station's logo on panels of a new generation of radio receivers in automobiles.

- POCKET CONVERGENCE: FM RADIO ON SMARTPHONES IN NORTH AMERICA

Speaker: Skip Pizzi - Vice President, Technology Education and Outreach (NAB)

The inclusion of FM radio receivers in North American smartphones has been an interesting and at times difficult process - not for technical but for business reasons. This presentation will cover the technology, the history, current status and future prospects of FM radio penetration in the N. American smartphone market.

- THE RADIOPHONE PROJECT - PROMOTING THE ACTIVATION OF FM IN CELLULARS IN BRAZIL

Speaker: ALEXANDRE BARROS - Presidente da Associação das Emissoras de Radiodifusão do Paraná - AERP Diretor do Grupo Maringá de Comunicação

This presentation will discuss the Brazilian perspective, the activation of FM chips in cell phones, the challenges and opportunities. Will also present the Radiophone Project, an initiative of AERP ( Association of Radio Stations of Paraná State) to promote the activation of chips in Brazil. 


\section{- THE FM IN THE CELL PHONE AND THE POSSIBILITY OF} REGULATION IN BR

\section{Speaker: Andre Ulhoa Cintra - Radio Director - ABERT}

This lecture will present the vision of ABERT on the activation of FM in mobile phones in Brazil. The possibility of making activation mandatory through regulation will also be discussed.

\section{- EXHIBITION OF LOGOMARCA IN AUTO-RADIOS AND SECURITY OF RDS SIGNAL}

\section{Speaker: MATHIAS MICHAEL OEELEIN - Radio Data Center (RDC)}

This lecture will present the project Radio Data Center, a technology that allows to show the station's logo on the panels of a new generation of radio receivers in automobiles. RDS is one of the technology references to identify the tuned station. To prevent that misuse of the IP by third parties implies in identification errors, the platform has resources to verify the source of the signal. The new technology is already working in Brazil on MOPAR easy4u receivers used in the FIAT and Chevrolet fleets. Mercedez Bens will begin using the technology in Brazil in 2018. ABERT and AMIRT support the project and some broadcasters are already participating.

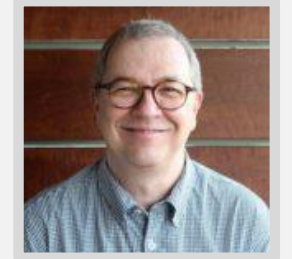

\section{Marco Túlio Nascimento - director of ZYDigital / SET}

Telecommunications Engineer graduated in 1983 from Universidade Federal Fluminense.With a career in the area of broadcasting, worked in the Radio Globo System where he held the position of General Manager of Technology and was responsible for the Engineering, IT and Operations areas. He is currently the director of ZYDigital, a company he founded in 2015 focused on technology consulting such as business support and development of media engineering solutions. He is deputy director of SET's Radio Market Segment.

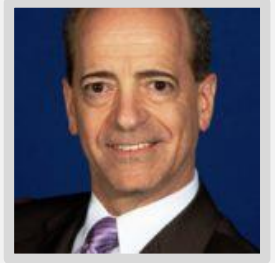

\section{Skip Pizzi - Vice President, Technology Education and Outreach (NAB)}

Skip Pizzi is Vice President, Technology Education and Outreach, at the National Association of Broadcasters (NAB) in Washington, DC, USA. His career has spanned the broadcast and digital media industries, working in audio engineering at NPR, and in audio production, media standards and technical policy at Microsoft. He was also an editor at Broadcast Engineeringmagazine, and a columnist for several other international industry publications. He remains a technology journalist, editor, author and trainer today. His most recent book is A Broadcast Engineering Tutorial for NonEngineers, 4th edition, published by Focal Press. He is currently Associate Editor on the NAB Engineering Handbook, 11th edition, which will be published later this year. Skip serves as ViceChair of the Advanced Television Standards Committee (ATSC) Technology Group 3 (TG3), which is developing the ATSC 3.0 standard. He is also a member of the Board of Directors of the Ultra HD Forum. Skip is a graduate of Georgetown University, where he studied Electrical Engineering, International Economics and Fine Arts. 


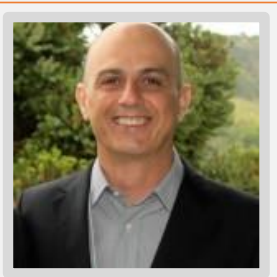

\section{Alexandre Barros - Presidente da Associação das Emissoras de Radiodifusão do Paraná - AERP Diretor do Grupo Maringá de Comunicação}

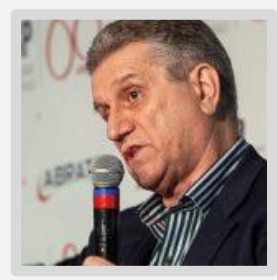

\section{Andre Ulhoa Cintra - Radio Director - ABERT}

Communications Engineer - Consultant specialized in the planning of broadcasting channels. Director of Radio Abert and currently working on the FM Channel, by ABERT to accommodate the migrant channels. Developed by SET work to accommodate the TV channeling in the process of planning the TV Digital TV channeling.

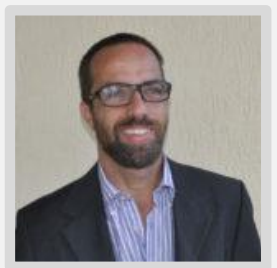

\section{Mathias Michael Oeelein - Radio Data Center (RDC)}

MATHIAS MICHAEL OEELEIN, German, represents the company Radio Data Center (RDC) in Brazil since 2014. The DRC is a German company which operates internationally in the Consulting area at the reception frequency of the stations, providing and evaluating all factors, including the topographic data and broadcasting. The DRC also acts providing and implementing logos of broadcasting radio, in the most modern multimedia systems in automobiles. He has a law degree in Germany and Brazil, specialized in contractual and negotiation law, international speaker and author of numerous guides to contractual law, published by the international chambers of commerce of Germany, Austria, Denmark and Poland. Mathias Oefelein is responsible for the implementation of the DRC project in Brazil, aiming at legalizing the use of logos in the new generations of vehicular multimedia systems. 